\title{
The Culture as System, the System of Culture: Aleksandr Bogdanov on Proletarian Culture and Proletarian Art
}

\author{
MAJA SOBOLEVA \\ Philipps University of Marburg, Germany; email: soboleva@staff.uni-marburg.de \\ Commentary by FRANCES NETHERCOTT
}

\begin{abstract}
Keywords: Aleksandr Bogdanov, organization, tektology, culture, art, system, proletarian
In my paper, I first focus on Aleksandr Bogdanov's systems theoretical understanding of culture and highlight the tektological foundations of culture. In this part, I analyze his organizational account of culture and interpret his tektological approach as a theory of the social dimensions of culture and the cultural dimensions of society. Second, I discuss the term 'proletarian culture', its definition and its role in Bogdanov's theory of socialism. I argue that Bogdanov's vision of a future socialist society is connected with establishing a socialist culture. He considers the proletariat a bearer of socialist ideology and deduces its unique political role from its unique position in the system of social knowledge. With his idea of proletarian culture, Bogdanov drafts a programme of proletarian evolution which challenges Lenin's programme for proletarian revolution. My last step concerns Bogdanov's account of proletarian art. I argue that, in order to understand Bogdanov's concept of art properly, we should differentiate between the terms 'culture' and 'art'. The category of culture appears to be a form of organization of a social group, and the category of art is a form of aesthetic self-understanding and self-expression of a social group. My analysis focuses on proletarian art as a form of the self-consciousness (ideology) of the working class.
\end{abstract}

\section{Tektological Foundations of Culture}

Amongst Bogdanov's numerous scientific and philosophical texts, Tektology, the universal organizational science, is undoubtedly his most significant contribution to the history of ideas. This work is usually considered to be the first fundamental variant of general systems theory and a precursor of cybernetics. In my book on Bogdanov's theoretical legacy, I argue that it is also the first project of a total socialist modernization of society on a scientific basis with its own tactics and strategies (Soboleva 2007: 146-172). Now, I like to stress one specific aspect of this work, namely, its relevance for the theory of culture. The key word of my approach can be formulated as 'culture as an organizational system'. 
The tektological approach to culture has some distinct features which must be articulated. First of all, there is no contradiction between the terms 'nature' and 'culture' here. Bogdanov argues: 'Nature is the first and the greatest organizer; and a human being is only one of its organized creations. The simplest living cell, observable only when magnified a thousand times by a microscope, far exceeds everything that man is able to organize in terms of the complexity and perfection of its organization. Man is just the student of nature, and so far a poor one' (Bogdanov 1996: 7). Thus, nature in general and human beings in particular are the subjects of the organizational processes. Therefore, the ways of spontaneous organization in nature and the methods of conscious organizational work of humanity can be analyzed by means of the same scientific methodology.

In fact, Bogdanov conceives Tektology as the 'science of sciences' which is primarily concerned with discovering a formal unity of the world. He argues that the whole universe consists of complexes which in turn consist of elements interrelated and organized in specific ways. The term 'complex' is Bogdanov's synonym for the modern term 'system'. It means the way things exist, whereupon existence is a process and, at the same time, a result of organization. The term 'complex' refers to an unspecific generalization which can be applied to the description of all possible material and ideal structured objects.

Bogdanov introduces a dynamic model of the world that describes it as an eternal, continual organizational process, an infinitely unfolding canvas of forms of different types and levels of organization - from the simplest elements of inorganic nature to human collectives and cosmic systems. One important aspect of this tektological ontology is that a complex cannot be separated from its environment; moreover, it can be differentiated and defined only against the background of its environment. Methodologically, a complex is not a constant substance but rather a changeable structure which can belong to different systems depending on the researcher's point of view. Thus, Bogdanov's ontology can be characterized as a structural ontology that deals not with individual objects but with the underlying structures of these objects, including their inner and outer formations.

Bogdanov's monistic approach is the reason why Tektology is aimed at the discovery of the general laws of organization. It does not describe and explain the details of isolated phenomena but rather studies the complex structures taken in their totality and their dynamic interactions with each other. That is why Bogdanov's new science aspires to work out a universal methodology, and it does not make any sharp divisions into branches and disciplines. Tektology is interdisciplinary and embraces not only chemistry, physics, biology and mathematics but also economics, cultural theory, education, psychology, medicine, linguistics, sociology and political sciences. Every phenomenon, including culture, can be analyzed from the organizational point of view - that is, as a system of universal organizational and de-organizational processes.

Bogdanov's understanding of cultural and social phenomena is sometimes regarded as a scientist's or even a naturalist's version of cultural reductionism that tries to explain different phenomena in virtue of homogeneous structural-functional methods. From this perspective, he was criticized, for example, by Johann Plenge (1874-1963). In his book review of the German translation of Tektology (1925), Plenge excoriates Bogdanov for the universalism of his theory which gives 'an inorganic picture of the mechanical-materialist reality of universal organization' (das 'unorganische Bild einer mechanistisch-materialistischen Gesamtwirklichkeit universaler Organisation') (Plenge 1927: 24). Its shortcomings are the 'unlimited generalization' and the 'simplified view of reality' (Plenge 1927: 20). In contrast to Bogdanov, Plenge develops his own theory of organization not as 'a general structural theory of all being' but as a social science. He claims: 'The real theory of organisation needs a foundation in a living spirit' ('Die wirkliche Organisationslehre braucht das Fundament des lebendigen Geistes') (Plenge 1927: 24). According to him, the task of this theory is 'to centralize human will and to activate it as a whole' ('menschlichen Willen zur Einheit zusammenzufassen und als Einheit zu betätigen') (Plenge 1965: 28-29). 
In defence of Bogdanov against this criticism, one could say that the tektological approach underlies a dialectic of the general and the particular. In conformity with this dialectic, every system - natural or social - operates according to its own particular structural laws. When applied to culture, Tektology changes its focus: it becomes a study of social dimensions of culture and a study of cultural dimensions of society. It assumes that the cultural system is determined by socio-economic organization of society, on the one hand, and that cultural traditions and institutions are objective only insofar as they have organizational functions, on the other. Bogdanov argues: 'The organizing form is much wider and more general .... This is the whole intellectual culture of the collective: the combination of its customs, morals, laws, its knowledge and its art, immersed in one and the same world-outlook specific to it - its outlook on life and its method of constructing life' (Bogdanov 1990: 136). By accenting the importance of culture for forming society, Tektology made a significant contribution to Marxism.

Bogdanov argues that the sphere of culture has a logic of its own and describes this logic in terms of 'social causality'. The category 'social causality' must demonstrate the dependence of cultural phenomena (knowledge, beliefs, norms, traditions, etc.) upon labour practices, methods and relationships. In his short historical excursion into forms of knowledge, Bogdanov highlights the correlation between knowledge and organization of labour. He differentiates mental and manual, organizational and executive forms of labour. For him, labour specialization connected with the separation of organizers from those who carry out orders has determined some historical models of social cognition, among which he names individualism, authoritarianism, conservatism, traditionalism and pragmatism. In his analysis, Bogdanov stresses that social organization of labour impacts the structure of knowledge and, therefore, the whole cultural landscape of historical society. He uses the term 'sociomorphism' to describe this correlation between epistemological (and cultural) representations and underlying labour activity. ${ }^{2}$ Bogdanov's universal mechanism of organization of epistemic and cultural experience is 'substitution'. The substitution can be seen as a complex, stepwise, expanding process of constructing symbolic reality through the subordination of some mental complexes to others. As a result, a certain sum of elements is selectively combined and united in social representations, corresponding to the historical needs and interests of certain social groups. ${ }^{3}$

Identifying knowledge and culture with collective experience, Bogdanov moves to a social epistemology; this is a radical departure from a classical individualist theory of knowledge. In regard to culture, the term 'organization' builds the quintessence of his constructivist approach. Everything sensual data, everyday meanings and theoretical concepts - is a product of the social organization of collective experience based on working conditions.

Bogdanov's approach to the analysis of cultural phenomena combines structural functionalism and historical methods. ${ }^{4}$ He posits society as an organizing institution and defines culture as a developing system of normative beliefs, as 'ideology' which is represented by historical social groups and institutions. The scope of ideology is very broad; it embraces theoretical and practical knowledge, religious and moral norms, aesthetical ideas and worldviews. The practical problem that Bogdanov confronted was the heterogeneity of cultural patterns within a class society. According to him, the cultural split within society was an important limiting factor for its progressive development. Therefore, Tektology was expected to pursue its practical agenda by transforming the culture of a contemporary society from capitalist to socialist.

To sum up, Bogdanov's account of culture is functionalist: it implies that culture is a special organizational complex which can be understood by means of general scientific methods. At the same

2 The term 'sociomorphism' can be traced back to the 'basic metaphor' of Max Müller that stresses the universal application of anthropological patterns in cognition of the world. According to Bogdanov, 'the basic metaphor is the embryo and prototype of the unity of the organizational point of view of the Universe' (Bogdanov 1996: 16).

3 Significant research into the term 'substitution' is delivered by Daniela Steila in her paper 'From Experience to Organisation: Bogdanov's Unpublished Letters to Bazarov' in Oittinen 2009: 151-172.

4 This claim can be proved by analysis of such works as Bogdanov 1904 and 1918. 
time, the tektological approach to the culture is clearly based on the premise that culture as a system possesses its own standards of logical consistency and semantic congruence although it is essentially connected with the social and economic organization of society. According to these theoretical points, culture finds its objective reality in the interactively established and co-ordinated collective representations which have organizational functions and depends upon the social orientations and social structures that influence these representations.

\section{Bogdanov's Idea of Proletarian Culture}

In his uncompleted and unpublished paper Ot filosofii k organizacionnoj nauke (From Philosophy to the Organisational Science) (1922), Bogdanov writes that there are two ideas which he has been developing and propagating throughout his life. They are the idea of general organizational science and the idea of proletarian culture (Bogdanov 1995b: 119). He wrote a number of works in which he developed the idea of proletarian culture. They are: Novy mir (The New World) (1904-1906); Kul'turnye zadachi rabochego klassa (Cultural Tasks of the Working Class) (1911); Iskusstvo i rabochij klass (Art and the Working Class) (1918); Sozialism nauki (The Socialism of Science) (1918); Elementy proletarskoj kul'tury v razvitii rabochego klassa (Elements of Proletarian Culture in the Development of the Working Class) (1920); O proletarskoj kul'ture (On Proletarian Culture) (1904-1924). To this list two novels can be added: The Red Star (1907) and The Engineer Menny (1912).

What is culture according to Bogdanov? In his texts we can find different formulations of the same principal idea. For example, in the talk Linii kul'tury v XIX i XXvv (The Lines of Culture in the 19th and 20th Centuries) (1920), he says that 'cultural principles of collectives are nothing else than organisational principles of their labour and struggle' (Bogdanov 1995c: 119). In the talk Mirovaja vojna i revoljucija (The World War and Revolution) (1921), he defines culture as 'a sum of organisational forms and methods of a class' (Bogdanov 1995a: 98). In his draft Ot filosofii k organizaionnoj nauke (From Philosophy to the Organisational Science) (1922), he claims that the inherent culture of a class consists of the 'organisational methods and the organisational, or ideological, forms they create' (Bogdanov 1995b: 115). Assuming that culture is a form of systematization of social cognitive experience and that every social group desires to organize the world in accordance with its own purpose, Bogdanov concludes that culture plays an essential role in organization of social life.

His idea of proletarian culture is focused on the concept of the proletariat. He considers the proletariat as a bearer of socialist ideology and an executor of the socialist reorganization of society. Bogdanov tries to substantiate this unique political role of the proletariat ontologically in the very nature of the contemporary working class which is defined by the methods of its work, and in its unique position in the system of social knowledge. He assumes, firstly, that modern industrial work is more sophisticated and includes both physical and intellectual elements because of the scientific character of modern technology and, secondly, that it is collective because of the high concentration and specialization of work. The first factor is a condition for the workers' consciousness becoming more scientific and rational; the second for developing a new morality, namely of the comradely, that is, 'consciously collectivist' relations. Thus, Bogdanov argues that the very logic of scientific-technical development determines that the working class cultivates both collectivist and rational thinking. And because of its scientifically founded rationality and technologically founded solidarity, it can play a leading role in political transformation of society on the way to socialism. An ability to think rationally and collectively makes the proletariat an 'organizer-class' (Bogdanov 1990: 216), a 'universal class' that can represent the interests of the whole society.

To fulfil its historical mission, the working class should be properly educated. Bogdanov repeated constantly that the working class in Russia, because of its exploited and oppressed condition and 
because it was culturally deprived, would not come forward politically if it did not form a proletarian class consciousness, that is, if it did not develop itself towards the Proletariat. I like to highlight that Bogdanov differentiates between the terms 'working class' and 'proletariat': the first refers to the fact; and the fact is that the Russian working class is a heterogeneous, culturally backward mass of people driven by egoistic interests. The latter represents Bogdanov's ideal. The Proletarian - written with a capital letter - is his version of a New Man; it is an ultimate goal of political education of the working class, symbolizing an ideal human being who combines rationalism and collectivism in their mentality.

Bogdanov's programme of proletarian culture, which can be reconstructed on the base of his numerous articles, is aimed at the forming of a materialist, monistic scientific worldview, ${ }^{5}$ a constructive, rationalist understanding of society based on the 'norms of expediency' and a 'conscious collectivism, that is, anti-individualism and recognizing of commonality of civil interests within the working class. What is important, according to Bogdanov, is that the proletariat should acquire all these qualities and build its self-identity before it receives political power. ${ }^{6}$ In this way, Bogdanov moves the revolutionary problems from the field of economy into the field of ideological structure? These ideas can be evaluated as modernization of Marxism. Instead of the proletarian revolution, Bogdanov drafts in his texts on proletarian culture a programme of the proletarian evolution. To Marx, 'communist consciousness' was a product of the social revolution, not its prerequisite (Marx \& Engels 1974: 44). To Bogdanov, proletarian culture is, on the contrary, not a consequence but a condition of socialist modernization of society.

The debates over proletarian culture continued in the period between 1905 and 1932. Bogdanov's most significant opponents were Trotsky and Lenin. In contrast to Bogdanov, Trotsky believed that 'there is no proletarian culture, and that there never will be any and in fact there is no reason to regret this. The proletariat acquires power for the purpose of doing away forever with class culture and to make way for human culture' (Trotsky 1960: 185-186). According to him, the period of the dictatorship of the proletariat should be temporary; it is necessary only for the transition from one social system to another, from capitalism to socialism. There are many political and economic problems that must be solved during this transition period. Trotsky was convinced that 'at any rate, the twenty, thirty, or fifty years of proletarian world revolution will go down in history as the most difficult climb from one system to another, but in no case as an independent epoch of proletarian culture' (Trotsky 1960: 190). According to him, what marks this transition period is the coexistence of different types of culture.

In Trotsky's opinion, 'such terms as "proletarian literature" and "proletarian culture" are dangerous, because they erroneously compress the culture of the future into the narrow limits of the present day' (Trotsky 1960: 205). Instead of the term 'proletarian culture', he suggests using the terms'revolutionary culture' and 'socialist culture'. The first is to be applied to the contemporary period of time; the last describes an ideal future society. Trotsky's rejection of the term 'proletarian culture' can be explained by his understanding of culture. He defined culture as 'the organic sum of knowledge and capacity which characterizes the entire society, or at least its ruling class. It embraces and penetrates all fields of human work and unifies them into a system. Individual achievements rise above this level and elevate it gradually' (Trotsky 1960: 200).

Despite all the differences between Bogdanov and Trotsky in the understanding of the concept of 'proletarian culture' - for the former, proletarian culture is a necessary condition of socialism, and for the latter, it is a consequence of socialism - there are some points that unite them. It is, first of all, an understanding of culture in general as ideology which influences a mass consciousness and underlies and penetrates all social structures and social praxis. The term 'culture' implies the way people relate

5 Bogdanov writes in his paper Puti proletarskogo tvorchestva (The Ways of Proletarian Art) that 'the methods of proletarian work are developing toward monismus and conscious collectivism' (Bogdanov 1918: 195).

6 For example, we read in Nauka i rabochij klass (Science and Working Class) that the proletariat should acquire science not after the socialist revolution but before it and for it' (Bogdanov 1990: 208).

7 This opinion is also represented by Rullkötter 1974: XIV. 
to the world and to each other. In the sense of Bogdanov and Trotsky, the concept of culture refers to a consciousness, a dominant worldview and a lifestyle (praxis); it refers to the forms of knowledge, skills, values, dispositions and expectations. Using Pierre Bourdieu's terminology, culture in Bogdanov's and Trotsky's theories can be characterized as a habitus of a social group. The creation of proletarian/ socialist culture demands the creation of new elements of socialism in the proletariat itself, in its conditions of life and in its internal and external relations.

In contrast, Lenin's attitude to proletarian culture was very different. According to him, the task of the proletariat was not to create a new culture within capitalism but rather to overthrow capitalism through a revolution for a new socialist culture. He admitted that the October Revolution had political character and saw the most important task of the Bolshevik party after the Revolution in the creation of supporters for the Soviet regime by means of forming a specific mentality and a specific moral amongst the people. In his uncompleted draft O smeshenii politiki s pedagogikoj (Concerning the Mixing [of] Politics and Pedagogics), he writes: 'In the political activity of the social-democratic party there is and will be a certain element of pedagogics: we must educate the working class toward its role as a fighter for freedom of humanity from exploitation ... The social-democrat who would forget this, would not be a social-democrat' (Lenin 1967: 357). It is obvious that he promotes the idea of political pedagogics. Lenin's attention to the proletarian culture movement after the October Revolution can be explained through his vision of establishing a new political-pedagogical space.

In fact, the proletarian culture movement of the 1920s fulfilled merely the functions of social-political pedagogics aiming to transform Russian inhabitants into Soviet citizens (in the terms of Andrey Zhdanov). The Proletkult movement advocated a new popular art by opening studios, theatres, clubs, workshops and artistic classes, by creating a new language and new forms of aesthetic expression. It also dedicated itself to literacy, to adult education, to matters as elementary as proper hygiene, family relations, the struggle against alcoholism and the struggle for a civil everyday life. The movement for proletarian culture spread across Soviet Russia in the early years of the Revolution and acquired a complex social and intellectual character. It was partly directly inspired by the ideas of Bogdanov, but this new movement proved to be very far removed from Bogdanov's original project of a social, cultural, moral and political education of the working class which he considered the 'socialist revolution in the working class' (Bogdanov 1995a: 100).

Although Bogdanov was convinced of the immaturity of the October Revolution 1917 - in his opinion, the working class was absolutely unprepared for its revolutionary role ${ }^{9}$ - he collaborated with the Proletkult movement and continued to promote his programme of proletarian culture. For example, straight away after the October Revolution, Bogdanov wrote the article Programma kul'tury (The Program of Culture) (1917) where he recommended to the workers 'to direct all its efforts toward mastering of the organisational means and their systematic working out according to the scale of the problems' (Bogdanov 1990: 332). In his paper Nauka i rabochij klass (Science and Working Class) (1918), Bogdanov specifies the concrete steps of his programme of proletarian education as including the development of a 'general science' as a universal methodology that would allow the regulation of nature and the carrying out of socialist transformations of society. He repeated constantly that the working class, because of its organic weaknesses, its ideological immaturity and a lack of ideological autonomy, would not step up to its function as an organizer-class if it did not collect organizational experience and adopt organizational tools. 


\section{Proletarian Art}

Bogdanov's conception of proletarian art is mostly formulated in such articles as O khudozhestvennom nasledstve (On Artistic Heritage) (1918), Kritika proletarskogo iskusstva (Criticism of Proletarian Art) (1918), Prostota ili utonchennost' (Simplicity or Subtlety) (1920), Proletariat i iskusstvo (The Proletariat and Art) (1920) and Vozmozhno li proletarskoe iskusstvo? (Is Proletarian Art Possible?) (1924). In these papers, he develops an organizational point of view on art. For example, in his article Is Proletarian Art Possible?, Bogdanov states paradigmatically that art is not just a 'decoration of life'; rather, it is 'one of the ideologies of a class, an element of its class consciousness; therefore, it is an organizational form of a class life, a way of association and consolidation of the class forces' (Bogdanov 1990: 413). In the paper Ot filosofi k organizacionnoj nauke (From Philosophy to the Organizational Science) (1922), he repeats that 'all ideological forms - language, thinking and concepts, norms of tradition, justice and moral, and images of art - are organizational tools (organisationnye orudija) of peoples' social life, their collective labor and struggle' (Bogdanov 1995b: 114). Thus, he stresses the social function of art.

Assuming that art is a form of organization of collective experience and that the proletariat should become a dominant and politically self-sufficient social group, one could expect that it must acquire its own ideology, and, hence, develop its own art. In fact, in the paper Proletariat i iskusstvo (The Proletariat and Art), Bogdanov highlights that 'the proletariat needs collectivist art which would bring up people in the spirit of deep solidarity, comradely cooperation, a close brotherhood of the fighters and the builders connected by the general ideal' (Bogdanov 1990: 442).

To understand Bogdanov's concept of art properly, one should differentiate between the terms 'culture' and 'art'. While culture has a purpose to transform the proletariat into the 'organizer-class', art is a form of aesthetic self-understanding and self-expression of the mature proletarian consciousness. ${ }^{10}$ The main issue of proletarian art is, hence, a specific ideal. This ideal must correspond with the nature of the working class that consists in the ability to organize the world's society on a new ideological rationalist and comradely - fundament. For Bogdanov, the proletariat organizes an external matter in a product through its work; it organizes itself in a creative collective not only by means of class fight but also by means of comradely co-operation; and it organizes its own experience in an identical class consciousness in order to be able to organize the whole of mankind for achieving a harmonic life. Unlike Lenin and Trotsky, who accented the necessity of class struggle and encouraged a military spirit in the proletariat, Bogdanov believed that'the working class goes to his ideal through the fight, but this ideal is not destruction, but the new organization of life' (Bogdanov 1918a: 67). Thus, his ideal of proletarian art is constructive and positive - including collectivist consciousness and 'comradely relationships' - because it should correlate to the socialist reorganization of society. It is, in Bogdanov's terms, the 'all-organizational' ideal.

Some authors, like Lynn Mally, thematize only one aspect of Bogdanov's theory of culture - namely, the aspect of the struggle of exploited workers against the bourgeoisie (Mally 1990). However, this approach contradicts the key idea of the tektological worldview which is consequently developed by Bogdanov in all his texts. Here, he rejects reduction of art to a communist propaganda and criticizes the one-dimensional understanding of art as merely'civil art' focusing on agitation and representing and protecting narrow class interests. He advocates the broad content of proletarian art: 'The whole life and the whole world' should be the content of proletarian art because its main task is to organize the 'soul of the proletariat' (Bogdanov 1990: 423). He writes: 'In thousands of poems calling for a class struggle and glorifying victories in that struggle, in hundreds of stories denouncing capital and its servants, everything else is submerged. This must be changed. The part should not be taken

10 For example, Bogdanov (1918a: 39) writes in the paper O khudozhestvennom nasledstve (On Artistic Heritage) that poetry is a part of the self-awareness of a class. 
as being the whole' (Bogdanov 1918a: 67). He appeals for the 'comprehensive deepening into life', for the 'comprehensive understanding of life, its concrete forces and its ways' (Bogdanov 1918a: 67). Everything can be the content of proletarian art; there are no restrictions for it. Thus, the perception of the world from the perspective of the proletarian ideal does not exclude that human life has many aspects which are all-human. What Bogdanov suggests can be interpreted as a kind of balance between the human and the social.

One more prejudice about Bogdanov's account of proletarian art should be dispelled: its attitude to the bourgeois culture. Bogdanov is often associated with radical intellectuals who define proletarian culture as unique and justify absolute rejection of cultural heritage. This image is absolutely wrong. On the contrary, Bogdanov outlines the necessity of cultural traditions created by prior social formations for the development of proletarian art and challenges the belief that proletarian art can emerge without cultural grounds. He argues that bourgeois culture has to be adopted in such a creative way that it becomes enrichment for the proletariat. The proletariat should study from previous generations, but its study must be accompanied by reflection about its own social perspective."1 Adapting a traditional culture, the proletariat should not 'obey' but 'rule': 'The new logic has to transform all these old things, to give old things other images ... But one must have this new logic, that is one must develop it' (Bogdanov 1990: 420). Against the left-radical-orientated propagandists of the autonomous proletarian art, Bogdanov argued that 'we live not only in a present-day collective, we live in a collaboration [sotrudnichestvo] between generations [Bogdanov's emphasis]. One should not confuse this with collaboration between classes; this is an opposite idea' (Bogdanov 1990: 425). Thus, the proletariat's attitude towards non-proletarian art should be, then, not nihilistic but complementary.

Another important point concerns the radical difference among Bogdanov, Lenin und Trotsky in regard to political attribution of art. For Lenin, art must not just become proletarian; it must be party art. He formulated this principle for literature (Lenin 1967: 48). However, he was referring to literature not in a narrow sense of the word but in terms of a wide range of artistic activity in general. For Lenin, any idea of an absolute autonomy of literature, art for art's sake, or the idea of an absolute freedom of writers, is simply an anarchist and reactionary bourgeois rhetoric. In contrast, Bogdanov distinguishes between the 'proletariat'as a class and 'party'. He recognizes collective forms of aesthetic production as an integral element in the process of social changes that demonstrate class character. In his own words: 'The artistic talent is individual, but creation is a social phenomenon: it emerges out of a collective and returns to a collective, serving its vital purposes' (Bogdanov 1990: 425). For society where the proletariat plays a dominant political role, the basis for the 'organization of our art as well as the organization of our science' must be 'comradely cooperation' (Bogdanov 1990: 425). The party model of organization of art suggested by Lenin is unacceptable for Bogdanov because of its authoritarian structure and domination-submission hierarchy that will inevitably give rise to authoritarian tendencies in a society.

Instead of a party's censorship and control over art, as proposed by Lenin, Bogdanov advocates an art and literary criticism which he conceives as a necessary organizational tool helping to develop proletarian art. ${ }^{12}$ The proletarian literary criticism should teach the working-class writers how to maintain their class position and class interest in their works. Bogdanov expects from the proletarian literature that it should depict life not from a subjective and naive point of view but against the background of a deep class understanding of a social context and proletarian goals. He expresses the idea that, in works of art, the individual should represent the typical; this is a means for working out the proletarian class-consciousness through the mechanism of identification of an individual with an ideal.

11 James D. White has the same opinion. He writes: In older cultures there were elements that were useful to the proletariat, but there were also others that were harmful. This being the case, the proletariat had to learn to distinguish what was beneficial from what was harmful and alien to it in the heritage of the past' (White 2013: 34).

12 This is the topic of the paper O kchudozhestennom nasledstve (On Artistic Heritage). 
But, at the same time, proletarian art must be objective. Bogdanov argues: 'As the organizer of life, art has to be, first of all, consequently sincere and truthful; whom and what can it organize if nobody trusts it?' (Bogdanov 1918a: 69) He stresses that, in playing its organizational function, art should not forget that 'the spirit of labour collectivism consists primarily in objectivity' (Bogdanov 1918a: 71).

Last but not least is a question about the form of proletarian art. One can expect that even pure aesthetics will receive in Bogdanov's theory a tektological foundation. In fact, Bogdanov claims in Tektology: 'The principles of a work of art are agreement and harmony, and therefore organization' (Bogdanov 2003: 3). Later, he repeats that beauty is'organizedness' (Bogdanov 1990: 426). He propagates the correlation between form and content and proposes to look for the forms which correspond with genuine proletarian activity, with aesthetics of industrial working process and scientific technology. ${ }^{13}$ Such a form must be simple, direct, constructive and expressive. It must be economic and, at the same time, it must clearly exhibit the content of an artwork. Form must express the rhythm of a new proletarian art which corresponds to proletarian labour activity. Bogdanov speaks not only about the 'rhythm of sounds' but also about the 'rhythm of images and ideas.' Form and rhythm should build a unity to be able to bring out the content in the best way. Summing up his position, I can say that Bogdanov represents a constructivist and functionalist view on art. After October 1917, this account of art was taken up almost immediately and stimulated a wide variety of artistic experiments in Russia.

\section{Commentary by Frances Nethercott}

In his classic study The Making of the English Working Class (1963), the British Marxist historian Edward Thompson broke ranks with orthodoxy by introducing an important distinction between 'class' as something we experience and class consciousness as that which we articulate through our lifestyle choices, customs, values - in short, in cultural terms: 'Class happens', he wrote,

when some men, as a result of common experiences (inherited or shared), feel and articulate the identity of their interests as between themselves, and as against other men whose interests are different from (and usually opposed to) theirs. The class experience is largely determined by the productive relations into which men are born - or enter involuntarily. Class-consciousness is the way in which these experiences are handled in cultural terms: embodied in traditions, value-systems, ideas, and institutional forms. If the experience appears as determined, class-consciousness does not. (Thompson 1963: 9-10)

The setting of Thompson's remarks - a study of the Industrial Revolution in late eighteenth-century Britain - is, of course, a long way from the situation faced by Russian Marxists during a period of political revolution in the early twentieth century. Yet, it is nonetheless striking that, in the wake of the October Revolution, it was precisely questions relating to the formation of collective identity and the quest for methodologies with which to uncover the distinctiveness of the proletarian worldview which became a focal point in the struggle among Marxist thinkers over cultural values and institutional control. As one of the leading figures of Proletkult, Bodganov reserved the highest place for art in this process of identity formation. While he believed that everything, from sensual data, everyday meanings to theoretical concepts, was causally related to the social framings, or organization, of collective experience, the artistic expression of that experience was something more; it harnessed a form of aesthetic self-understanding and self-expression that was peculiar to a given social group. For Bogdanov, it followed that art presents one of the most powerful articulations of collective identity; 
moreover, given the distinctive qualities of proletarian aesthetic and cultural self-understanding, its artworks could become a key weapon in the task of organizing and promoting class forces. More than reflecting the world, proletarian art would transform it.

Bogdanov was undoubtedly one of the most creative thinkers in Revolutionary Russia whose work, in recent years, has found resonances across a range of disciplines: as we know, it has received attention from Western scholars as a contribution to systems theories and cybernetics and has even been read as confirmation of current thought about the Anthropocene. Still, his credentials as an innovative Marxist thinker, particularly in light of his approach to culture and to art as a distinctive expression of class-based collectivist cultural values, are worth restating. Maja Soboleva's analysis of Bogdanov's conceptual terminology is a reminder that, even as a committed Marxist, he challenged some of the established orthodoxies of his age.

\section{References}

Biggart, J.; Dudley, P. and King, F. (eds.) 1998. A. Bogdanov and the origins of systems thinking in Russia. Aldershot, England and Brookfield, Vermont: Ashgate.

Bogdanov, A. 1904. Iz psichologii obshchestva. Stat'i 1901-1904. Sankt Peterburg: Dorovatovskiy and Charushnikov.

Bogdanov, A. 1916. Mirovye krizisy, mirnye i voennye. Petrograd: Letopis'. №3, 139-163; №4, 133153; № 5, 113-124; № 7, 214-238.

Bogdanov, A. 1918. Nauka ob obshchestvennom soznanii. Kratkiy kurs ideologicheskoy naukiv voprosakh i otvetakh. Moskva: Knizhnoe izdatel'stvo pisateley v Moskve.

Bogdanov, A. 1918a. Iskusstvo i rabochiy klass. Moskva: Proletarskaya kul'tura.

Bogdanov, A. 1990. Voprosy socializma. Moskva: Izdatel'stvo politicheskoy literatury.

Bogdanov, A. 1995a. Mirovaja vojna i revoljucia (The World War and Revolution) (1918). In Neizvestnyy Bogdanov. V trekh knigakh, edited by G.A. Bordyugov. Kniga 1, 92-108. Moskva: IC AIRO-XX.

Bogdanov, A. 1995b. Ot filosofii k organizacionnoj nauke (From Philosophy to the Organisational Science) (1922). Neizvestnyy Bogdanov. V trekh knigakh, edited by G.A. Bordyugov. Kniga 1, 110-119. Moskva: IC AIRO-XX.

Bogdanov, A. 1995c. Linii kul'tury XIX i XX vv. (The Lines of Culture in 19th and 20th Centuries) (1920). In Neizvestnyy Bogdanov. V trekh knigakh, edited by G.A. Bordyugov. Kniga 1, 119-137. Moskva: IC AIRO-XX.

Bogdanov, A. 1995d. Otkrytoe pis'mo Bukharinu. In Neizvestnyy Bogdanov. V trekh knigakh, edited by G.A. Bordyugov. Kniga 1, 204-207. Moskva: IC AIRO-XX.

Bogdanov, A. 1996. Tektology. Book 1 edited and translated by Vadim Sadovsky, Vladimir V. Keille and Peter Dudley, University of Hull: Centre for Systems Studies.

Dudley, P. and Poustilnik, S. 1996. Reading the Tektology: Provisional Findings, Postulates and Research Directions. Center for Systems Studies. The University of Hull. Reseach und memorandum. No. 11.

Lenin, VI. 1967. Polnoe sobranie cochineniy. Izdanie 5-oe. Tom 10, 335-358. Moskva: Izdatel'stvo politicheskoy literatury.

Mally, L. 1990. Culture of the Future. Berkeley and Los Angeles: University of California Press.

Marx, K. and Engels, F. 1978. German Ideology, excepted in On the Socialist Revolution. Moskva: Izdatel'stvo politicheskoy literatury. 
Oittinen, V. (ed.) 2009. Aleksandr Bogdanov Revisited. Helsinki: Gummerus Printing.

Plenge, J. 1927. Um die allgemeine Organisationslehre. Weltwirtschaftliches Archiv. 25. Band: 18-29.

Plenge, J. 1965. Deutsche Propaganda (1921). Johann Plenges Organisations- und Propagandalehre, eingeleitet von Hanns Linhard. Berlin: Duncker \& Humblo.

Poustilnik, S. 1995. Printsip otbora kak osnova Tektologii A. Bogdanova. Voprosy filosofii. № 8.

Rullkötter, B. 1974. Die wissenschaftliche Phantastik der Sowjetunion. Bern, Frankfurt am Main: Lang.

Sadovskiy, VN. 1995. Empiriomonizm A.A. Bogdanova: zabytaya glava filosofii nauki. Voprosy filosofii. № 8.

Soboleva, M. 2007. Aleksandr Bogdanov und der philosophische Diskurs in Russland zu Beginn des 20. Jahrhunderts. Zur Geschichte des russischen Positivismus. Hildesheim: Olms Verlag.

Thompson, EP. 1963. The Making of the English Working Class. London.

Trotsky, L. 1960. Literature and Revolution. The University of Michigan Press.

White, JD. 2013. Alexander Bogdanov's Conception of Proletarian Culture. Revolutionary Russia. 26, $1,52-70$.

\section{Authors information}

Dr Maja Soboleva is Extraordinary Professor of Philosophy, Philipps University of Marburg. She studied chemistry in St Petersburg and philosophy in St Petersburg, Erlangen and Marburg. She received a doctor's degree in chemistry in 1992, a PhD in philosophy in 2000, and habilitated in philosophy 2005. In 2008-2009 she was the Mildred Miller Fort Visiting Scholar in European Studies at Columbus State University (USA). Since 2007 she has been a lecturer, a research associate and privat-docent (since 2010) at Philipps University of Marburg (Germany). In 2013 she won a Visiting Fellowship Award in Russian and Eastern European Studies from the Aleksanteri Institute in Helsinki (Finland). Further, in 2014-2015 she was a full professor of philosophy at Alpen-Adria University, Klagenfurt and in 2019-2021 a Lise-Meitner Senior Research Fellow at the same university.

Frances Nethercott is Reader in Modern Russian History at the University of St Andrews, Scotland. Her most recent monograph, Writing History in Late Imperial Russia: Scholarship and the Literary Canon, was published by Bloomsbury in 2020.

\footnotetext{
○

OPEN ACCESS

Copyright: $\odot 2021$ The Author(s). This is an open-access article distributed under the terms of the CreativeCommons Attribution 4.0 International License (CC-BY 4.0), which permits unrestricted use, distribution, andreproduction in any medium, provided the original author and source are credited. See http://creativecommons.org/licenses/by/4.0/.
} 